\title{
Evaluasi Reflektif Pengembangan Karakter Bangsa (Nasionalisme) Dalam Pendidikan Agama Buddha Tingkat Sekolah Dasar
}

\author{
Hesti Sadtyadi \\ STAB N Raden Wijaya Wonogiri Jawa Tengah, Indonesia \\ 15hestisadtyadi@gmail.com
}

\begin{abstract}
The Objective of this Study is to a reflective evaluation of Indonesian national character in the education of Buddhism in elementary schools, which can produce a picture that poures national values character (nationalism) in the context of learning that is administered. The reflective evaluation is carried out with the CIPP evaluation model, which includes five constructs and five reflective Buddhism educational instruments wich consits of context dimensions, the teacher's interest, the teaching materials, the learning process and the product. All instruments are valid and reliable. The result of the development of the reflective evaluation instrument of Buddhist education that has been built consists of five aspects / dimensions of evaluation with the name Context, Teachers' Knowledge / Interest (Input), Materials (Input), Process and Product (Product). The content of the nation's character in Buddhism is explicit in the components of History, Faith (Saddha), Behavior or Morality (Sila), Buddhist holly Books (Tipitaka), Meditation (Samadhi), and Wisdom (Panna), accumulated in context, input, process, and output, through the evaluation of the Buddha's education refelective in the development of the nation's character.
\end{abstract}

Keywords: reflective evaluation, nation character

\begin{abstract}
Abstrak
Penelitian ini bertujuan untuk melakukan evaluasi reflektif karakter bangsa Indonesia dalam pendidikan agama Buddha di Sekolah Dasar, yang dapat menghasilkan gambaran penuangan nilai-nilai karakter bangsa (nasionalisme) dalam kontek pembelajaran yang diselenggarakan. Evaluasi reflektif dilakukan dengan model evaluasi CIPP, yang mencakup lima konstruk dan lima instrumen yang terdiri atas dimensi konteks, minat guru, bahan ajar, proses pembelajaran dan produk. Semua instrumen valid dan reliable. Hasil pengembangan intrumen evaluasi reflektif pendidikan agama Buddha telah dibangun terdiri atas lima aspek/dimensi evaluasi dengan nama Konteks (Context), Pengetahuan/Minat guru (Input), Bahan Ajar (Input), Proses (Process), dan Produk (Product). Muatan karakter bangsa dalam agama Buddha tertuang secara explisit dalam komponen Sejarah, Keyakinan (Saddha), Perilaku/moral (Sila), Kitab Suci Agama Buddha Tripitaka (Tipitaka), Meditasi (Samadhi), maupun Kebijaksanaan (Panna), yang terakumulasi dalam konteks, input, proses, maupun output, melalui evaluasi refelektif pendidikan agama Buddha dalam pengembangan karakter bangsa.
\end{abstract}

Kata kunci: evaluasi reflektif, karakter bangsa

Permalink/DOI: http://dx.doi.org/10.18326/infsl3v12i2.371-394 


\section{Pendahuluan}

Indonesia sebagai negara yang berkembang, dengan telah melakukan program-program pembangunannya. Orientasi dalam pembangunan diarahkan agar dapat mencapai kesejahteraan bagi bangsa Indonesia. Pencapaian kemajuan bangsa yang telah dilakukan tahap demi tahap, semestinya tidak meninggalkan tujuan atau cita-cita negara yang tercantum dalam Undang-Undang Dasar Negara Indonesia. Beberapa bentuk program pembangunan yang telah dilakukan termasuk melalui kerjasama dengan pemerintah Amerika Serikat. Khususnya terkait dengan pendidikan Sekolah Dasar, telah diprogramkan secara bertahap untuk meningkatkan kemampuan anak sekolah dasar (Usaid; 2013). Sedangkan upaya yang dilakukan untuk pendidikan dasar melalui rencana pembangunan jangka menengah adalah mempercepat peningkatan taraf pendidikan seluruh masyarakat untuk memenuhi hak seluruh penduduk usia sekolah dalam memperoleh layanan pendidikan dasar yang berkualitas. Meningkatkan Pencegahan Korupsi, pada aspek preventif, diperlukan peningkatan upaya pencegahan korupsi dengan meningkatkan kesadaran dan pemahaman anti-korupsi masyarakat dan penyelenggara negara melalui strategi pendidikan anti korupsi mulai dari pendidikan dasar (Badan Perencanaan Pembangunan Nasional, 2014). Upaya yang tidak kalah penting dan terkait adalah menempatkan pendidikan karakter, dengan melakukan revolusi mental dimulai dari pendidikan sekolah dasar, termasuk dalam hal ini pendidikan agama.

Kemajuan yang telah dicapai bangsa Indonesia dalam hal pembangunan fisik harus diimbangi dengan pembangunan non-fisik, diantaranya membangun karakter dan jati diri bangsa. Pembangunan karakter bangsa melalui pendidikan agama Buddha dengan tidak meninggalkan rasa Nasionalisme, sangatlah penting dilakukan. Pentingnya pembangunan karakter dan jati diri bangsa telah diamanatkan dalam Undang-Undang Dasar Negara Republik Indonesia Tahun 1945 agar Pemerintah Indonesia mengusahakan dan menyelenggarakan satu sistem pendidikan nasional yang meningkatkan keimanan, ketakwaan kepada Tuhan Yang Maha Esa, dan akhlak mulia serta mencerdaskan kehidupan bangsa. 
Beberapa permasalahan dalam membangun karakter dan jati diri bangsa agar menjadi bangsa yang kokoh adalah telah terjadi disorientasi dan belum dihayatinya nilai-nilai Pancasila, keterbatasan perangkat kebijakan terpadu dalam mewujudkan nilai-nilai esensi Pancasila, bergesernya nilai-nilai etika dalam kehidupan berbangsa dan bernegara, memudarnya kesadaran terhadap nilai-nilai budaya bangsa, dan ancaman dan gangguan terhadap kedaulatan negara.

Pendidikan agama harus menjadi rujukan utama (core values) dan menjiwai seluruh proses pendidikan dan pengembangan ilmu pengetahuan dan teknologi, maupun pendidikan karakter. Pendidikan agama di sekolah seharusnya memberikan warna bagi lulusan pendidikannya, khususnya dalam merespon segala tuntutan perubahan dan dapat dipandang sebagai acuan nilai-nilai keadilan dan kebenaran, dan tidak semata hanya sebagai pelengkap. Dengan demikian, pendidikan agama menjadi semakin efektif dan fungsional, mampu mengatasi kesenjangan antara harapan dan kenyataan dan dapat menjadi sumber nilai spiritual bagi kesejahteraan masyarakat dan kemajuan bangsa.

Kajian ruang lingkup Pendidikan Agama Buddha ini mencakup enam aspek yang terdiri atas: (1) Keyakinan (Saddha); (2) Sila; (3) Samadhi; (4) Panna; (5) Tripitaka (Tipitaka); dan (6) Sejarah. Hal tersebut merupakan bagian dari pendidikan agama Buddha. Keenam aspek tersebut merupakan kesatuan yang terpadu dari materi pendidikan agama Buddha yang mencerminkan keutuhan ajaran agama Buddha dalam rangka mengembangkan potensi spiritual peserta didik. Aspek keyakinan yang mengantar ketakwaan, moralitas, dan spiritualitas maupun penghargaan terhadap nilai-nilai kemanusiaan dan budaya luhur akan terpenuhi. Permasalahanya adalah bagaimana pendidikan agama Buddha menjadi bagian dari karakter bangsa, dan sejauhmana nilai-nilai dalam agama Buddha menjadi karakter bangsa.Permasalahan yang mendahului untuk dapat menilai hal tersebut adalah indikator dan komponen yang manakah dari agama Buddha yang merupakan karakter bangsa?

Sebagai pembatasan masalah, dan sekaligus rumusan masalah dalam penelitian ini adalah: Bagaimana evaluasi reflaktif karakter bangsa Indonesia dalam pendidikan agama Buddha di Sekolah Dasar? 


\section{Kajian Teori Evaluasi Refleksi Pendidikan Karakter dalam Pendidikan Agama Buddha}

Berkaitan dengan karakter, pendidikan agama Buddha dan evaluasi reflektif. Sigmund Freud, mengatakan bahwa karakter adalah atribut psikologis yang menunjuk pada cara atau kebiasaan seseorang dalam bertindak berpikir dan bereaksi yang membedakan individu dengan individu yang lainnya (Saifuddin \& Karim, 2008:48). Karakter seseorang terbentuk dari pengalaman masa kecilnya, kemudian mengkonstruksi cara berpikir, bersikap, dan berperilaku seseorang tanpa disadarinya. Karakter bangsa adalah kualitas perilaku kolektif kebangsaan yang khas yang tercermin dalam kesadaran, pemahaman, rasa, karsa, dan perilaku berbangsa dan bernegara sebagai hasil olah pikir, olah hati, olah rasa dan karsa, serta olah raga seseorang atau sekelompok orang (Pemerintah Republik Indonesia, 2010:7). Pendidikan agama Buddha dapat menjadi ujung tombak pembentukan pola pikir dan karakter siswa bergama Buddha yang menyiapkan siswa menjadi, warga negara yang handal dapat dilihat dari bagaimana karakter bangsa (nasionalisme) terbentuk.

Evaluasi harus dilakukan secara berkesinambungan pada seluruh aspek pendidikan agama Buddha sekolah dasar secara utuh dengan memperhatikan pertanyaan-pertanyaan penting tentang tujuan, elemen-elemen dalam perencanaan awal, apakah elemen dalam perencanaan awal sudah sesuai dengan tujuan pembelajaran dan kurikulum yang berlaku serta karakteristik peserta didik, kualitas interaksi antara peserta didik dan guru, performa guru dan peserta didik selama dalam proses pembelajaran, dan apakah tujuan yang ditetapkan telah tercapai (Davis, 1980:23).

Evaluasi reflektif pendidikan Agama Buddha akan mampu menangkap adanya penuangan karakter bangsa (nasionalisme) dalam suatu perencanaan dan implementasi pendidikan yang diperlukan dan sekaligus sebagai alat control. Untuk itu, evaluasi reflektif pendidikan agama Buddha haruslah dirancang berdasarkan konstruk teori dari teori pendidikan dan nasionalisme bangsa Indonesia dalam menentukan komponen dan indikator model evaluasi yang akan dikembangkan. Berdasarkan telaah teori pendidikan, Model evaluasi CIPP (Context, Input, Process, Product) 
dari Stufflebeam dan koleganya dipandang merepresentasikan sebagian besar komponen yang harus dimiliki, oleh satuan pendidikan agama Buddha.

\section{Hakikat Fungsi dan Tujuan Pendidikan Agama Buddha}

Pendidikan Agama Buddha adalah usaha yang dilakukan secara terencana dan berkesinambungan dalam rangka mengembangkan kemampuan peserta didik untuk memperteguh keimanan dan ketakwaan kepada Tuhan Yang Maha Esa dan berakhlak mulia, serta peningkatan potensi spiritual sesuai dengan ajaran agama Buddha (BSNP, 2006; 97).

Pendidikan Agama Buddha merupakan rumpun mata pelajaran yang bersumber dari Kitab Suci Tripitaka (Tipitaka), yang dapat mengembangkan kemampuan peserta didik dalam memperteguh iman dan takwa kepada Tuhan Yang maha Esa, Triratna, berakhlak mulia/budi pekerti luhur (sila), menghormati dan menghargai semua manusia dengan segala persamaan dan perbedaannya (agree in disagreement).

Menurut Peraturan Pemerintah Nomor 55 Tahun 2007 tentang Pendidikan Agama dan Pendidikan Keagamaan, disebutkan bahwa: Pendidikan Agama berfungsi membentuk manusia Indonesia yang beriman dan bertakwa kepada Tuhan Yang Maha Esa serta berakhlak mulia dan mampu menjaga kedamaian dan kerukunan hubungan inter dan antarumat beragama (Pasal 2 ayat 1). Selanjutnya, disebutkan bahwa pendidikan agama bertujuan untuk berkembangnya kemampuan peserta didik dalam memahami, menghayati, dan mengamalkan nilai-nilai agama yang menyerasikan penguasaannya dalam ilmu pengetahuan, teknologi dan seni (Pasal 2 ayat 2$)$.

Tujuan pendidikan agama sebagaimana yang disebutkan di atas itu juga sejalan dengan tujuan pendidikan agama Buddha yang meliputi tiga aspek dasar yaitu pengetahuan (pariyatti), pelaksanaan (patipatti) dan penembusan/ pencerahan (pativedha). Pemenuhan terhadap tiga aspek dasar yang merupakan suatu kesatuan dalam metode Pendidikan Agama Buddha ini yang 
akan mengantarkan peserta didik kepada moralitas yang luhur, ketenangan dan kedamaian dan akhirnya dalam kehidupan bersama akan mewujudkan perilaku yang penuh toleran, tenggang rasa, dan cinta perdamaian.

\section{Kurikulum Pendidikan Agama Buddha}

Kurikulum Pendidikan Agama Buddha yang berbasis standar kompetensi dan kompetensi dasar mencerminkan kebutuhan keragaman kompetensi secara nasional. Standar ini diharapkan dapat dipergunakan sebagai kerangka acuan dalam mengembangkan Kurikulum Pendidikan Agama Buddha sesuai dengan kebutuhan daerah atau pun sekolah. (BSNP, 2006; 97). Pendidikan Agama Buddha meliputi aspek-aspek sebagai berikut.1. Sejarah; 2. Keyakinan (Saddha); 3. Perilaku/moral (Sila); 4. Kitab Suci Agama Buddha Tripitaka (Tipitaka); 5. Meditasi (Samadhi); 6. Kebijaksanaan (Panna).

\section{Evaluasi Pendidikan Agama Buddha}

Fokus utama dari evaluasi yang bersifat refleksif atau yang menggunakan pendekatan reflektif pada pendidikan agama Buddha adalah berusaha memahami proses pelaksanaan pembelajaran, termasuk dialog, wacana, bentuk dan tema diskusi, serta jenis wacana dan isu yang berkembang dalam interaksi dan komunikasi dengan para guru sebagai pelaksana pembelajaran, maupun komponen terkait dengan pendidikian. Dengan demikian, apa yang menjadi sasaran evaluasi reflektif adalah, bagaimana proses pembelajaran terjadi, apakah terdapat penuangan pengembangan karakter bangsa dalam kaitannya dengan pendidikan agama Buddha yang ditanamkan dalam proses pembelajaran mulai dari kurikulum tertulis sampai dengan kurikulum yang tidak tertulis (bidden curriculum) yang dipantau dari bentuk tugas, tes, dan kegiatan belajar di kelas.

Dalam hal ini, feedback adalah elemen yang penting dalam proses reflektif. Peserta didik harus dapat memahami feedback yang diberikan oleh guru maupun peserta didik lainnya dan 
mengaplikasikannya dalam pembelajarannya demi memaksimalkan kompetensinya di hari-hari berikutnya. Selain feedback dari guru atau rekan, penilaian dari peserta didik sendiri tentang kemajuan belajarnya yang dikenal dengan self assessment juga menjadi masukan yang sangat penting. Dalam konteks pendidikan agama Buddha, self-assessment dipandang cocok dilakukan melalui guru serta komponen yang memungkinkan untuk dilakukan evaluasi, karena sudah lebih matang dalam berpikir dan mandiri dalam perkembangan karir dan profesionalisme di masa depannya nanti. Tidak hanya guru, komponen lainnya juga dapat memanfaatkan masukan dari guru, maupun guru lainnya, maupun refleksi diri sendiri dalam bentuk self-assessment sebagai refleksi pengalaman mengajar dan belajar yang telah diberikan selama ini termasuk efektivitasnya dan perubahan-perubahan yang diperlukan demi perbaikan mutu pembelajaran kedepannya.

Terdapat beberapa metode kegiatan evaluasi reflektif, yang dapat dikembangkan dalam melakukan evaluasi yang bersifat reflektif, yaitu metode Data, metode Critical Thinking, metode Experiential Learning, metode Action Research, metode Critical Incident, metode Concept Map, dan metode Storytelling (Kuit, Reay, \& Freeman, 2001:131-135). Dari ketujuh metode dalam kegiatan refleksi yang disebutkan di atas, metode Experiential Learning memiliki karakteristik yang erat dengan kegiatan evaluasi reflektif, yaitu mendasarkan pada konsep learning cycle sehingga dapat dipandang relevan dengan konsep evaluasi reflektif yang merupakan fokus dari penelitian ini.

Wening (2007:25) menyatakan bahwa dalam evaluasi reflektif yang dilakukan adalah kegiatan penggambaran, pencarian, dan pemberian informasi tentang kebutuhan siswa yang dilakukan dengan cara mendokumentasikan dan melihat kembali pengalaman, pemikiran, perilaku, strategi, dan kejadian-kejadian yang sudah dilakukan yang dapat mengungkap kembali kelemahan dan kelebihannya serta menggunakan hasilnya sebagai informasi untuk pertimbangan perbaikan yang akan datang.

Kegiatan evaluasi reflektif ini penting dilakukan oleh guru karena dapat memberikan pengalaman dari merefleksi, 
memperbaiki keterampilan-keterampilan mengajar. Melalui refleksi dapat menjadikan guru lebih cerdas dan efektif dalam proses pembelajaran. Wening (2007) berpendapat bahwa tahapan dalam kegiatan evaluasi reflektif tersebut dapat memberikan guru memiliki kemampuan merespon dan melakukan perubahan terhadap halhal yang tidak diharapkan. Oleh karena itu, penggunaan evaluasi reflektif sekaligus dapat meningkatkan kepekaan guru dalam mencari solusi terhadap tiap masalah yang dihadapi secara kontekstual di lingkungan guru. Evaluasi reflektif dalam penelitian ini merupakan kegiatan pengumpulan data tentang pembelajaran, telaah sikap, keyakinan, anggapan, dan pengalaman belajar yang dilakukan oleh guru maupun yang dialami peserta didik melalui perenungan serta pertanyaan-pertanyaan yang dilakukan agar dapat melihat kembali semua pengalaman belajar di dalam ke kelas sebagai bekal memperbaiki kualitas pembelajaran.

\section{Model Evaluasi Pendidikan}

Proses pelaksanaan evaluasi pendidikan agama Buddha harus dilaksanakan secara terus menerus, secara berkesinambungan pada tiap aspek, baik perencanaan secara utuh dengan memperhatikan pertanyaan-pertanyaan penting tentang tujuan, elemen-elemen dalam perencanaan awal, apakah elemen dalam perencanaan awal sudah sesuai dengan kebutuhan, muupun tujuan, juga karakteristik peserta didiknya. Apa yang dikehendaki terkait dengan kualitas interaksi antara peserta didik dan guru, performa guru dan peserta didik selama dalam proses pembelajaran, dan apakah tujuan yang ditetapkan telah tercapai (Davis, 1980:23). Dalam hal ini peranan guru dalam melakukan evaluasi pendidikan agama Budha menjadi sangat strategis karena guru sebagai agen evaluasi adalah pihak yang dapat dengan jelas mengobservasi, mendeskripsikan, dan menganalisis interaksi di dalam kelas.

Model evaluasi CIPP dirancang dengan menentukan dahulu informasi apa saja yang diperlukan, apa yang harus direncanakan untuk dilakukan dalam memperoleh informasi yang diperlukan kedalam empat kategori, yaitu Context, Input, Process, dan Product dalam suatu urutan logis dengan penekanan pada pengumpulan 
informasi untuk memfasilitasi perbaikan suatu pendidikan agama Buddha. Model CIPP adalah model evaluasi yang diperkenalkan oleh Daniel Stufflebeam pada tahun 1971, (Davis, 1980:49). Dengan kata lain, perbaikan pendidikan agama Buddha didasarkan pada data (informasi) yang diperoleh dalam kegiatan evaluasi context, input, process, dan product.

\section{Metode Penelitian}

Penelitian ini merupakan penelitian pengembangan, yang menggunakan mixed method yaitu kualitatif dan kuantitatif. Pendekatan campuran digunakan untuk menjembatani halhal yang berpeluang muncul yang tidak dapat diatasi dengan mempergunakan satu metode. Penelitian ini menggunakan metode purposive sampling dalam pemilihan sampel, di mana pemilihan jumlah subjek di sesuaikan dengan keadaan di lapangan di mana penelitian dilaksanakan. Subjek penelitian melibatkan responden di wilayah Provinsi Jawa Tengah, yang meliputi guru dan siswa Beragama Buddha.

Analisis kualitatif yang digunakan dalam kajian pustaka untuk membangun teori terkait konstruk dan kriteria, mendeskripsikan penilaian pakar terhadap konstruk, kriteria, dan model yang dikembangkan, dan hasil uji coba kelompok terbatas maupun kelompok yang lebih besar menggunakan teknik cross-case analysis.

Analisis Kuantitatif mempergunakan analisis validitas, reliabilitas serta analisis factor yaitu Exploratory factor Analysis, dengan alasan, di agama Buddha belum pernah dilakukan penelitian. Dalam analisis Exploratory merujuk ketentuan yang berlaku seperti nilai aturan besaran terkait dengan validitas, reliabilitas. Peneliti menentukan bahwa instrumen yang dapat digunakan adalah yang memiliki nilai item-scale correlation $\geq 0,30$. Jika terdapat instrumen yang memiliki item-scale correlation antara 0.20-0.29 masih dapat digunakan dalam uji coba kedua namun perlu direvisi terlebih dahulu. Dengan ketentuan: (1) butir yang akan diterima apabila memiliki muatan faktor minimal 0,30, karena muatan faktor yang kurang dari 0,30 butir korelasinya rendah. 2) apabila butir memiliki 
lebih dari satu muatan faktor di atas 0,30 yang mendekati sama, maka butir tersebut digugurkan karena tidak berdimensi tunggal. Penggunaan kriteria muatan faktor minimal 0,30 mengacu pada Kim \& Muller (1978: 70) \& Coakes \& Steed (1996: 124). Untuk Exploratory, dengan standar nilai KMO, loading factor, maupun anti imagenya.

\section{Hasil Pengembangan dan Evaluasi Reflektif}

Evaluasi reflektif Pendidikan Agama Buddha Tingkat Sekolah Dasar dalam Pengembangan Karakter Bangsa (Nasionalisme) melalui tahap penelitian (pra-survei), dan tahap pengembangan. Kajian pustaka dan penelitian yang relevan, dilakukan sebagai tahap awal, selain dilakukan penggalian informasi dalam hal pendidikan agama Buddha yang berkaitan dengan karakter bangsa, khususnya untuk mendapatkan indikator dan komponen yang dapat digunakan dalam menyusun karakter bangsa. Penggalian informasi ini dilakukan berkaitan dengan materi dan bahan pendidikan agama Buddha, yang merupakan telaah terhadap kurikulum pendidikan agama Buddha tingkat sekolah dasar, terhadap pengetahuan dan kesiapan guru dalam proses pendidikan agama Buddha, terhadap pelaksanaan pendidikan agama Buddha, yang dilaksanakan di dalam kelas maupun lingkungan terkait oleh guru pendidikan agama Buddha, serta terhadap hasil pendidikan agama Buddha, serta upaya pendidikan agama Buddha dalam menuangkan muatan karakter bangsa dalam proses pembelajaran. Tahap pengembangan yang dilakukan adalah meliputi kegiatan pendefinisian, perancangan dan demonstrasi.

Kegiatan pendefinisian merupakan kegiatan untuk merumuskan komponen evaluasi dalam hal mendapatkan dan menemukan muatan karakter bangsa yang berada dalam pendidikan agama Buddha. Tahap perancangan dilakukan penyusunan instrumen yang dapat digunakan untuk melakukan evaluasi muatan karakter bangsa, yang ada dalam pendidikan agama Buddha, yang meliputi kontek kurikulum, pengetahuan guru pendidikan agama Buddha tentang pendidikan karakter, juga muatan karakter bangsa yang berkaitan dengan bahan ajar, proses belajar serta hasil dari produk belajar (afeksi), dalam hal muatan karakter bangsa. Kegiatan 
validasi sebanyak tiga kali dilakukan pada tahap perancangan dan sebelum melakukan uji coba di lapangan tahap I, dan sebelum dilakukan uji lapangan tahap II atau uji tahap akhir.

\section{Pendidikan Agama Buddha dan Penerapan Pendidikan Karakter} Bangsa

Tujuan utama pembelajaran pendidikan agama Buddha, sudah seharusnya selain mengembangkan kemampuan dan penguasaan peserta didik terhadap agama Buddha, juga mengembangkan rasa nasionalisme terhadap bangsa Indosesia, melalui karakter bangsa (nasionalisme/karakter kebangsaan). Pentingnya pendidikan karakter bangsa ini berkaitan dengan pendidikan agama dapat menjadi permasalahan sendiri jika dalam ajarannya hanya secara khusus keagamaan sehingga dapat menghasilkan siswa yang memiliki jiwa fanatisme terhadap agamanya. Memperhatikan komponen dalam penelitian ini dapat disampaikan bahwa penerapan pendidikan karakter dalam pendidikan agama Buddha sebagai berikut : (1) Kontek Kurikulum, masih dalam wujud secara implisit untuk diterapkan, hal ini tampak dari hasil penggalian data yang menunjukkan bahwa muatan dalam tujuan pembelajaran, rancangan silabus, dan penilaian kelas, belum dituangkan secara explisit, hal ini menunjukkan bahwa harus dilakukan peninjauan dan perbaikan. (2) Pengetahuan Guru tentang Pendidikan Karakter: meskipun pengetahuan guru tentang pendidikan karakter pada pendidikan agama Buddha sudah tinggi, tetapi pelatihan dalam bentuk kegiatan guru atau workshop pembekalan pengetahuan atau keterampilan belum terprogram, bentuk pembekalan dapat dijadikan kriteria eksternal dalam hal memastikan bahwa pengetahuan guru tentang pendidikan karakter terus ter-update; (3) Bahan Ajar: guru sebagai pengajar pendidikan agama Buddha memiliki otoritas yang besar dalam membawa proses belajar, tetapi selama ini belum ada mekanisme yang dapat digunakan untuk memeriksa muatan karakter dalam setiap bahan ajar yang diberikan; (4) Proses Pembelajaran: guru dan siswa adalah dua tokoh yang paling mengetahui apa terjadi di dalam kelas, dan selama ini belum ada evaluasi terhadap informasi tentang muatan karakter bangsa dalam proses pembelajaran baik 
itu dari guru maupun siswa; (5) Produk Pembelajaran Afeksi: penelusuran tentang produk pembelajaran afeksi karakter bangsa masih belum banyak disentuh demi memastikan internalisasi nilainilai kebangsaan dalam diri siswa.

Evaluasi Reflektif dilakukan melalui empat sub-aktivitas yaitu pendefinisian, perancangan, demonstrasi, dan pengembangan. Kegiatan pendefinisian meliputi perumusan komponen evaluasi untuk mengidentifikasi muatan karakter bangsa (nasionalisme/ karakter kebangsaaan) dalam kurikulum Pendidikan Agama Buddha. Evaluasi muatan karakter bangsa dalam kurikulum Pendidikan agama Buddha dapat diidentifikasi melalui empat aspek yaitu: (1) konteks kurikulum pendidikan agama Buddha; (2) input kurikulum pendidikan agama Buddha; (3) Proses Pembelajaran dalam kurikulum pendidikan agama Buddha; dan (4) Produk Pembelajaran Afeksi. Berdasarkan keempat aspek tersebut dapat ditentukan indikatorindikator yang merupakan bagian dari masing-masing aspek, yang selanjutnya ditentukan deskriptornya, dan penjabaran deskriptor menjadi butir-butir instrumen evaluasi reflektif pendidikan agama Buddha yang meliputi evaluasi konteks, evaluasi input, evaluasi proses, dan evaluasi produk.

Kegiatan perancangan meliputi kegiatan penyusunan kisi-kisi instrumen evaluasi reflektif Pendidikan agama Buddha dalam pengembangan karakter bangsa dan dilanjutkan dengan penyusunan instrumen evaluasi muatan karakter bangsa dalam konteks kurikulum pendidikan agama Buddha dengan jumlah butir 132 butir dengan sebaran 24 butir instrumen evaluasi muatan karakter bangsa dalam konteks kurikulum pendidikan agama Buddha, 30 butir instrumen evaluasi minat guru tentang pendidikan karakter, 20 butir instrumen evaluasi muatan karakter bangsa dalam bahan ajar, 29 butir instrumen evaluasi pengamatan kegiatan belajar peserta didik, dan 29 butir instrumen evaluasi produk pembelajaran afeksi (karakter bangsa siswa).

Butir-butir pada instrumen evaluasi muatan karakter bangsa dalam konteks kurikulum pendidikan agama Buddha dan pada instrumen evaluasi muatan karakter bangsa dalam bahan ajar disusun dalam format jawaban yang terdiri dari pasangan kata 
sifat dengan skala kategori bertingkat menggunakan model skala beda semantik seperti misalnya: eksplisit implisit. Pilihan jawaban di ujung sebelah kiri menunjukkan pernyataan yang paling sesuai atau paling dekat dengan apa yang diketahui, dipikirkan, atau dirasakan oleh responden dan demikian sebaliknya. Untuk mengetahui apakah indikator yang disusun dalam kisi-kisi sudah terwakili dalam instrumen dilakukan validasi, analisis, dan revisi. Validasi dilakukan melalui beberapa tahap dan uji coba dua kali dengan setiap tahapan validasi dan uji coba dilakukan analisis dan revisi.Uji keterbacaan dengan sejumlah praktisi, yang terdiri dari guru, dosen dan mahasiswa STAB N Raden Wijaya untuk mereview dan memvalidasi instrumen. Dalam uji keterbacaan tersebut dihadiri oleh 2 Dosen, 2 mahasiswa, dan guru pendidikan agama Buddha.

Setelah melakukan analisis dan pembahasan berdasarkan masukan dan review dari mahasiswa, dihasilkan bahwa instrumen tetap dalam komposisi sebagai berikut : jumlah butir 132 butir dengan sebaran 24 butir instrumen evaluasi muatan karakter bangsa dalam konteks kurikulum pendidikan agama Buddha, 30 butir instrumen evaluasi minat guru tentang pendidikan karakter, 20 butir instrumen evaluasi muatan karakter bangsa dalam bahan ajar, 29 butir instrumen evaluasi pengamatan kegiatan belajar peserta didik, dan 29 butir instrumen evaluasi produk pembelajaran afeksi (karakter bangsa siswa).

Hasil dari FGD berkaitan dengan, kisi-kisi, dan instrumen melalui teman sejawat ditindaklanjuti dengan melakukan perbaikan terhadap butir-butir pada instrumen. Setelah menyelesaikan revisi, dilakukan validasi ulang dengan mempergunakan 5 orang dosen dan mahasiswa. Validasi kedua ini meminta masukan tentang relevansi butir dengan indikator. Jumlah total butir pada instrumen evaluasi reflektif pendidikan agama Buddha dalam pengembangan karakter bangsa keseluruhan instrumen berjumlah 132 dengan rincian 24 butir instrumen muatan karakter bangsa dalam konteks, 30 butir instrumen evaluasi minat guru tentang pendidikan karakter, 20 butir instrumen evaluasi muatan karakter bangsa dalam bahan ajar, 29 butir instrumen evaluasi pengamatan kegiatan belajar peserta didik, dan 29 butir instrumen evaluasi produk pembelajaran afeksi (karakter bangsa siswa). 
Penilaian para ahli terhadap kejelasan tujuan evaluasi dan komponen model evaluasi muatan kebangsaan dalam pendidikan agama Buddha dinyatakan dalam bentuk penilaian baik. Sebagai hasil masukan dapat dinyatakan bahwa komponen tujuan sudah baik, dan tujuan evaluasi juga sudah jelas. Dalam hal kriteria penyekoran, pernyataan-pernyataan yang tercantum pada butir pada instrumen yang menggunakan skala beda semantik terdiri dari kata sifat yang positif di ujung kiri dan kata sifat yang negatif di ujung kanan. Pilihan positif memiliki skor tertinggi 5 , sedangkan pilihan negatif memiliki skor tertinggi 1 . Setiap pilihan jawaban yang dijawab berturut-turut dari ujung paling kiri sampai ujung kanan diberi skor 5, 4, 3, 2, 1 . Pernyataan-pernyataan yang tercantum pada butir pada instrumen yang menggunakan skala tipe Likert yang diadaptasi terdiri dari pernyataan positif dan negatif. Pernyataan positif memiliki skor tertinggi 5 , sedangkan pernyataan negatif memiliki skor tertinggi 1. Setiap pernyataan positif yang dijawab sangat sesuai diberi skor 5 , sesuai $=4$, kurang sesuai $=3$, tidak sesuai $=2$, dan sangat tidak sesuai $=1$.

Instrumen untuk evaluasi reflektif dalam pandangan dan masukan sejawat, disampaikan bahwa instrumen sudah sangat baik, dan disarankan untuk melihat dan membandingkan dari hasil uji coba, sehingga insttumen nantinya menjadi sangat sesuai baik dari tujuannya, maupun mempertimbangkan kemudahannya.

Setelah Validasi praktisi dilakukan pada saat melakukan uji coba tahap pertama, dimana responden guru selain diminta mengisi instrumen evaluasi juga diminta menilai dua aspek, yaitu (1) kejelasan instrumen, dan (2) kejelasan panduan evaluasi. Berdasarkan penilaian dan masukan dari praktisi dapat tergambarkan bahwa, instrumen sudah dinyatakan jelas, dengan panduannya, dengan penilaian baik.

\section{Uji Tahap I dan II}

Berdasarkan uji tahap I dan II, dihasilkan bahwa intrumen tidak berubah dari uji tahap I dan II. Evaluasi dokumen, tetap berjumlah 24, instrumen Minat Guru berjumlah 30, Instrumen Analisis Teks 
tetap berjumlah 20, Instrumen hasil belajar adalah 29, dan intrumen Kegiatan Belajar juga 29. Reliabilitas intrumen tergolong sangat baik, mulai uji tahap I, maupun uji tahap II, hal ini dapat dilihat dari nilai reliabilitas diatas 0,7 . Nilai KMO dari uji tahap I ke Uji tahap II juga tampak semakin baik, dengan kecenderungan semakin meningkat. Hal ini menandakan bahwa secara kualitas intrumen sudah baik, serta dapat digunakan untuk analisis.

Evaluasi Refletif Pendidikan Agama Buddha Sekolah Dasar

\section{Tabel 1. Evaluasi Reflektif Pendidikan Agama Buddha dalam Pendidikan Karakter Bangsa (Nasionalis)}

\begin{tabular}{ccccccccccc}
\hline Guru & \multicolumn{2}{c}{ Kontek } & \multicolumn{3}{c}{ Input Guru } & $\begin{array}{c}\text { Input } \\
\text { Bahan }\end{array}$ & Proses & \multicolumn{2}{c}{ Produk } \\
& EfR1 & EfR2 & EfR1 & EfR2 & EfR1 & EfR2 & EfR1 & EfR2 & EfR1 & EfR2 \\
\hline GB1 & 3 & 3,2 & 4 & 4,2 & 3 & 3 & 4 & 3,4 & 4 & 4 \\
GB2 & 3,5 & 3,6 & 4 & 4 & 2,8 & 3 & 4 & 3,6 & 4 & 4 \\
GB3 & 3,3 & 3,3 & 4 & 4 & 2,8 & 3 & 4 & 4,3 & 4 & 4 \\
GB4 & 3,4 & 3,6 & 4 & 4,1 & 2,8 & 3 & 4 & 4 & 4 & 4 \\
GB5 & 3 & 3,5 & 4 & 4 & 3 & 3 & 4 & 4 & 4 & 4 \\
\hline
\end{tabular}

Sumber Data : Hasil olahan, peneliti, 2015

$\mathrm{GB}=$ Guru Pendidikan Agama Buddha (SD)

EfR1 = Evaluasi Reflektif Tahap 1

EfR2 $=$ Evaluasi Reflektif Tahap II

Berdasarkan rata-rata hasil evaluasi reflektif, dari kontek, untuk lima guru pendidikan agama Buddha, yang diambil sebagai sampel, menunjukkan bahwa secara umum memiliki nilai 3, yang berarti komponen kontek dalam pendidikan agama Buddha, sudah cukup baik, dalam hal memuat karakter bangsa. Komponen input guru, memiliki nilai relatif sudah baik, hal ini menunjukkan bahwa berkaitan dengan muatan karakter guru pendidikan agama Buddha, sudah ada, baik dari minat atau motivasi dan segala bentuk persiapan yang dilakukan oleh guru. Efaluasi reflektif berkaitan dengan bahan, secara umum dalam kategori cukup, hal ini tampak dari bahan atau 
materi tentang pendidikan karakter, bersifat tersirat tidak tersurat, sehingga materi pendidikan agama Buddha, yang terdiri dari komponen sejarah, sadha, silla, bhakti, dan lainnya, tidak secara spesifik memuat karakter bangsa, tetapi merupakan pendidikan agama, dan makna karakter bangsa tetap berada tidak terpisahkan, karena agama merupakan bagian yang memperkuat rasa cinta dan banga sebagai bangsa Indonesia. Bahkan untuk karakter pancasila, yang merupakan keperilakuan, sangat sesuai serta merupakan bagian contoh model keperilakuan yang ada dalam agama Buddha, dan menjadi bagian dari materi pendidikan agama Buddha.

Berkaitan dengan evaluasi reflektif pendidikan agama Buddha, khususnya tentang bahan atau sumber buku, hal ini karena sumber buku pendidikan agama Buddha, sangat terbatas, dengan pengembangan di dalamnya masih bersifat materi agama saja, dan belum banyak dikembangkan. Melalui evaluasi refelktif ini, dapat digambarkan bahwa untuk bahan ajar dalam pendidikan agama Buddha, seharusnya dikembangkan lebih banyak, sehingga dalam proses belajar, cukup mudah untuk mendapatkannya. Evaluasi reflektif dalam hal proses maupun produk atau output, dihasilkan nilai yang baik, hal ini menandakan dalam proses pendidikan agama Buddha, terdapat proses yang tidak ditinggalkan yakni nilai karakter bangsa. Gambaran proses ini, dihasilkan baik dari intrumen yang menandakan komponen proses sudah memuat karakter bangsa melalui penilaian, juga terdapat hasil gambaran melalui diskusi dengan bapak ibu guru pendidikan agama Buddha, yang pada intinya mereka selalu memberikan contoh aplikasi keseharian yang bekaitan dengan cinta tanah air dan bangsa, serta perilaku keseharian yang mencerminkan sikap manusia Indonesia yang menerapkan sikap hidup dengan Pancasila.

Evaluasi reflektif terhadap produk, khususnya adalah hasil belajar, dihasilkan bahwa sikap nilai afektif siswa, tampak memiliki nilai baik dalam hal karakter bangsa. Hal ini didukung dengan hasil pengamatan dan masukan dari bapak ibu guru pendidikan agama Buddha, yang memberikan contoh keperilakuan sebagai hasil dari penerapan pendidikan agama Buddha terkait dengan karekter bangsa, sebagai contoh sikap tertibnya siswa dalam memperhatikan lingkungan kelasnya, sikap tidak membuang sampah sembarangan, 
dan aktif dan sangat bersemangat dalam mengikuti kegiatan sekolah, seperti upacara bendera.

Melalui evaluasi refelktif pendidikan agama Buddha, sekolah dasar dalam kaitannya dengan pendidikan karakter bangsa, dihasilkan bahwa secara umum komponen kontek, memiliki muatan karekter yang cukup baik, demikian halnya dari minat guru, bahan, pelaksanaan dan proses pembelajaran pendidikan agama Buddha, serta hasil belajarnya.

\section{Muatan Kebangsaan dalam Konteks pendidikan agama Buddha}

Hasil evaluasi muatan kebangsaan dalam konteks kurikulum pendidikan agama Buddha bahwa konteks kurikulum dari beberapa guru yang menjadi sampel dalam penelitian termasuk kategori kuat. Hal ini oleh guru pendidikan agama Buddha (Ketua KKG) dijelaskan bahwa pendidikan agama Buddha, disampaikan dengan tidak meninggalkan karakter bangsa peserta didik (siswa).

Dalam pelaksanaan kurikulum pendidikan agama Buddha menghimbau semua guru untuk menerapkan model pembelajaran yang sesuai, yang disarankan dalam kurikulum. Menurut keterangan salah seorang guru pendidikan agama Buddha, inti dari pembelajaran pendidikan agama Buddha juga merupakan pembelajaran reflektif, dimana siswa diharapkan mampu merefleksikan perkembangan pembelajaran mereka, terutama kekurangan dan kekuatan pembelajaran yang mereka terima selama ini. Bentuk konkrit dari pembelajaran reflektif ini adalah berupa evaluasi dalam suatu siklus pembelajaran, dimana siswa akan diminta melakukan refleksi setelah beberapa unit pembelajaran berakhir.

Dari penjelasan diatas dapatlah disimpulkan bahwa secara konteks, pelaksanaan kurikulum pendidikan agama Buddha sudah memiliki suasana seperti yang diharapkan dalam pendidikan karakter kebangsaan, atau nasionalisme.

Hasil evaluasi konteks kurikulum pendidikan agama Buddha dengan menggunakan instrumen evaluasi reflektif kurikulum pendidikan agama Buddha menunjukkan konteks kurikulum 
pendidikan agama Buddha kuat dengan muatan pendidikan karakter yang tidak tercantum secara eksplisit, namun masih perlu melakukan beberapa perbaikan, karena tujuan pembelajaran yang dituangkan dalam silabus masih bersifat implisit. Hal ini dibuktikan dengan evaluasi reflektif guru menunjukkan pada evaluasi konteks, hanya indikator tujuan pembelajaran yang dinyatakan sedikit kurang kuat dengan muatan kebangsaan atau nasionalisme padahal rancangan pembelajaran, penilaian kelas dan kelembagaan dinyatakan kuat dengan muatan kebangsaan atau nasionalisme.

Hal ini menunjukkan bahwa secara konteks para guru pendidikan agama Buddha sudah memiliki komitmen untuk menerapkan pendidikan karakter di dalam kurikulum pendidikan agama Buddha yang diselenggarakannya, namun masih belum berani secara terang-terangan atau eksplisit menyatakannya dalam silabus, ataupun rencana pembelajaran. Hal ini dapat menjadi informasi yang penting bagi Ditjen Bimas Buddha atau PTAB atau pihak yang bertanggung jawab untuk membina dan memastikan bahwa semua guru pendidikan agama Buddha telah mengimplementasikan fokus pencapaian tujuan pembelajaran yang sesuai dengan kurikulum serta muatan kebangsaan atau nasionalisme.

Hasil temuan evaluasi konteks diatas membuktikan bahwa workshop perlu diselengarakan untuk membantu dan memantau guru dalam menerapkan pendidikan karakter pada kurikulum pendidikan agama Buddha, termasuk di dalamnya muatan karakter kebangsaan.

\section{Pengetahuan guru tentang Pendidikan Karakter Bangsa}

Dari hasil evaluasi secara deskriptif dapat dijelaskan bahwa guru yang menjadi responden dalam penelitian ini termasuk kategori cukup baik pengetahuannya tentang pendidikan karakter bangsa, terutama dalam hal pengetahuan faktual dan prosedural. Guru lebih mementingkan bagaimana aplikasi dari pengetahuan tentang pendidikan karakter itu sendiri, meskipun mereka mengakui bahwa pengetahuan tentang konsep-konsep juga perlu tetapi akan lebih bermakna bila langsung dengan bagaimana implementasinya di dalam kelas. 


\section{Muatan Karakter Bangsa dalam Bahan Ajar}

Dari hasil evaluasi secara deskriptif dapat dijelaskan bahwa muatan karakter kebangsaan pada bahan ajar yang menjadi sampel dalam penelitian termasuk cukup kuat terhadap muatan karakter kebangsaan, meskipun dalam hal tema, teks dan tugas yang diberikan, dan juga kemenarikan dipandang masih kurang dalam hal muatan karakter kebangsaanya. Responden menyatakan bahwa bahan ajar dalam penelitian ini sudah kuat dengan muatan karakter kebangsaan dilihat dari keluasan bacaan yang bisa dikaitkan dengan masalah kebangsaan, dan juga sudah cukup terdapat contoh fiturfitur kebangsaan di dalam bahan ajar tersebut.

Dalam hal penetapan bahan ajar dalam pendidikan agama Buddha sekolah dasar, sangat tergantung dari pemerintah, karena, sumber bahan atau buku yang masih sangat kurang untuk didapatkan, dan bahkan tidak dijual untuk kalangan masyarakat umum, artinya tidaklah mudah untuk mendapatkan buku atau bahan ajar, yang dapat digunakan sebagai bahan ajar. Penetapan bahan ajar dilakukan dan dirumuskan melalui kelompok kerja guru, bahkan, kadang dikembangkan oleh Bapak/Ibu guru itu sendiri dalam rumpun KKG Pendidikan agama Buddha.

Kegiatan KKG pendidikan agama Buddha, membantu dalam melakukan refleksi pembelajaran yang dilakukan. Melalui refleksi dihasilkan masukan untuk memenuhi kekurangan yang ada, sehingga menjadi lebih sempurna. Diskusi dalam KKG Pendidikan agama Buddha dilakukan tiap pertemuan, sehingga menjadi lebih efektif.

\section{Muatan Karakter Bangsa dalam Proses Pembelajaran}

Hasil evaluasi muatan kebangsaan dalam proses pembelajaran menggunakan instrumen evaluasi reflektif pendidikan agama Buddha menunjukkan bahwa PBM yang menjadi sampel dalam penelitian pendidikan agama Buddha termasuk kategori cukup kuat/baik dengan muatan kebangsaan, utamanya dalam hal kegiatan belajar inti eksplorasi dan elaborasi. Hasil evaluasi muatan karakter bangsa 
dalam PBM menunjukkan bahwa menurut responden, kegiatan awal dan kegiatan konfirmasi masih dirasakan kurang dengan muatan kebangsaan.

Kegiatan belajar dalam PBM dipandang begitu penting dalam membantu siswa menguasai kemampuan, afeksi dan praktik beragama seperti penguasaan sadha, silla ataupun bhakti, juga sejarah. Melalui kegiatan pembelajaran pendidikan agama Buddha dengan muatan karakter bangsa, tentunya diharapkan akan membentuk sistem ketahana siswa/anak untuk memiliki jiwa nasionalis atau cinta terhadap tanah air dan bangsa, melalui pelaksanaan norma Pancasila dalam kehidupan sehari-hari.

Dapat disimpulkan bahwa pelaksanaan PBM untuk pendidikan agama Buddha, dalam kaitannya dengan pendidikan karakter sudah cukup kuat atau baik. Melalui pendidikan agama Buddha, seperti muatan tentang Sadha, Silla, Bhakti ataupun sejarah, maka akan membimbing siswa dalam berperilaku cinta tanah air dan bangsanya, melalui sikap hidupa dalam norma Pancasila.

\section{Produk Pembelajaran Afeksi}

Dari hasil evaluasi secara deskriptif dapat dijelaskan bahwa karakter kebangsaan siswa yang dilihat sebagai produk hasil pembelajaran afeksi yang diberikan dalam pendidikan agama Buddha menunjukkan bahwa responden yang terlibat dalam penelitian ini dipandang sudah kuat/baik karakter kebangsaannya, kecuali dalam hal valuing. Hasil evaluasi produk hasil pembelajaran afeksi menunjukkan bahwa menurut responden, mereka masih lemah dalam hal aktualisasi yang tampak. Hal ini dapat dijelaskan, dari kondisi siswa, yang tampak malu-malu, tapi pada saat kesempatan diberikan kepada mereka untuk menunjukkan kemampuannya, ternyata dapat menunjukkan yang lebih, sehingga gambaran aktualisasi atau nilai-nilai yang tergambarkan masih lemah, tetapi sesungguhnya sudah baik.

Sebagai evaluasi reflektif secara diskriptif dapat dijelaskan bahwa, proses pembelajaran akan selalu dengan hasil produk pembelajaran dalam bentuk penguasaan ilmu pengetahuan, dalam 
hal ini pendidikan agama Buddha, juga penguasaan afeksi, yang dapat dibentuk melalui pembelajaran yang penuh makna, sehingga wawasan kebangsaan dapat terbentuk, dengan baik.

\section{Simpulan}

Hasil penelitian dan pembahasan terhadap evaluasi reflektif pendidikan agama Buddha dalam pengembangan karakter bangsa (nasionalisme) dapat disimpulkan sebagai berikut: 1) Evaluasi reflektif ini mencakup lima konstruk dan lima instrumen evaluasi reflektif pendidikan agama Buddha bermuatan karakter bangsa yang terdiri atas dimensi konteks, dimensi minat guru, dimensi bahan ajar, dimensi proses pembelajaran dan dimensi produk pembelajaran afeksi. Pengukuran terhadap kontek bermuatan karakter bangsa yang disusun berdasarkan konstruk kurikulum bermuatan karakter bangsa fit (cocok), yang dapat dilihat dari KMO untuk keseluruhan, maupun tiap intrumen berdasarkan anti image dan loading faktornya, selain memperhatikan validitas dan reliabilitasnya. 2) Semua instrumen evaluasi reflektif pendidikan agama Buddha dalam pengembangan karakter bangsa telah teruji validitas dan reliabilitasnya, yaitu memiliki muatan faktor $>0,50$ dan reliabilitas lebih dari 0,70 , dengan rincian sebagai berikut: instrumen evaluasi muatan karakter bangsa dalam konteks berjumlah 24 butir, Instrumen Minat Guru tentang Pendidikan Karakter memiliki 30 butir, Instrumen Muatan Karakter Bangsa dalam Bahan Ajar berjumlah 20 butir, Instrumen muatan Karakter Bangsa dalam Proses Pembelajaran berjumlah 29 butir, dan Instrumen produk afeksi (siswa( berjumlah 29 butir). 3) Hasil pengembangan intrumen evaluasi reflektif pendidikan agama Buddha dalam pengembangan karakter bangsa yang telah dibangun berdasarkan kajian pustaka, penilaian rekan sejawat, dan praktisi, dan uji coba empirik terdiri atas lima aspek/dimensi evaluasi dengan nama Konteks (Context), Pengetahuan/minat guru (Input), Bahan Ajar (Input), Proses (Process), dan Produk (Product) yang dapat disingkat menjadi CIIPP (Context-Input-Input-Proses-Product). 4) Evaluasi reflektif yang dikembangkan ini terdiri dari seperangkat instrumen evaluasi, panduan penerapan kegiatan evaluasi dan kriteria penyekorannya 
yang dapat digunakan untuk memfasilitasi proses refleksi diri guru pendidikan agama Buddha terkait dengan karakter bangsa, yang diselenggarakannya, fit (cocok) dengan model yang didukung data empirik. 5) Muatan karakter bangsa dalam agama Buddha tertuang dalam komponen Sejarah, Keyakinan (Saddha), Perilaku/moral (Sila), Kitab Suci Agama Buddha Tripitaka (Tipitaka), Meditasi (Samadhi), maupun Kebijaksanaan (Panna), yang terakumulasi dalam konteks, input, proses, maupun output, melalui evaluasi refelektif pendidikan agama Buddha dalam pengembangan karakter bangsa.

\section{Daftar Pustaka}

Badan Perencanaan Pembangunan Nasional (2014), Rencana Pembangunan Jangka Menengah Nasional Tahun 20152019, Buku I Agenda Pembangunan Nasional, Kementerian Perencanaan Pembangunan Nasional, Jakarta.

BSNP, (2006). Standar Isi untuk Satuan Pendidikan Dasar dan Menengah.

Coakes, S.J. \& Steed, D. (1996). SPSS for Window: analysis without anguish. Australia: Jacaranda Wiley LTD.

Cumming R., Dyas, L., Maddux, C. D., \& Kochman, A. (2001). Principled moral reasoning and behavior of pre-servise teacher education student. American Educational Research Journal, 38 (1), 143-158

Davis, E. (1980). Teachers as curriculum evaluators. North Sydney, NSW: George Allen \& Unwin.

Fernandes, J. J. X. (1987). Evaluation of educational program. Jakarta: National Educational Planning Evaluation and Curriculum Development. 
Kim, J.O., \& Muller, C.M., (1986). Factor Analysis, Statistical Methods \& Practical Issues, London: Sage Publication, Inc.

Kuit, J. A., \& Reay, G., Freeman, R. (2001). Experiences of Reflective Teaching. Active learning in higher education, 2 (2), 128-142.

Marzuki.(Artikel) Pendidikan Karakter Dalam Keluarga Perspektif Islam.Diambil tanggal 23 Mei 2015, Jam 11.33 melalui http://staff.uny.ac.id/sites/default/files/ pengabdian/drmarzuki-mag/dr-marzuki-mag-prinsip-pendidikan-karakterperspektif-islam.pdf.

Parmenter, L. (1999). Constructing national identity in a changing world: perspectivein Japanese education. British Journal of Sociology of Education, 20, (4), 453-463.

Pemerintah Republik Indonesia. (2010). Kebijakan nasional pembangunan karakter bangsa tahun 2010-2025. http:// $\mathrm{www} \cdot \operatorname{google} \cdot \mathrm{com} / \# \mathrm{hl}=\mathrm{en} \& \mathrm{tbo}=\mathrm{d} \&$ output=search\&sclient =psyab\&q=kebijakan+nasional +pembangunan+karakter+ba ngsa+tahun +2010-2025\&gs/11-02-2013.

Peraturan Pemerintah Nomor 19 Tahun 2005, tentang Standar Nasional Pendidikan.

Saifuddin, A.F., \& Karim, M. (2008). Refleksi karakter bangsa. Jakarta: Penerbit Forum Kajian Antropologi Indonesia. Sanjaya, W. (2008). Kurikulum dan pembelajaran: teori dan praktik pengembangan kurikulum tingkat satuan pendidikan (KTSP). KENCANA PRENADA MEDIA GROUP.

Stufflebeam,D.L. \& Shinkfield, A. J, (1985). Systematic Evaluation. Boston: Kluwer Nijhof Publishing.

Stufflebeam,D.L, (1972). Education Evaluation and decition making. Itasca, Illionis: F.E. Peachock Publisher. Inc.

Undang-Undang Dasar Negara Republik Indonesia Tahun 1945.

Usaid, 2013. Investasi Pembangunan di Indonesia, Indonesia Yang Lebih Kokoh dalam Memajukan Pembangunan Nasional Dan 
Global, Jakarta.

Wening, S. (2007). Pembentukan karakter remaja awal melalui pendidikan nilai yang terkandung dalam pendidikan konsumen: kajian evaluasi reflektif

Worthen, B. R., \& Sanders, J. R., 1984. Educational evaluation: Theory and practice. Worthington, OH: Charles A Jones Publishing Company. 